\title{
A Study of Factors that Contribute to the Severe Progression of Peritonsillar Abscess
}

\author{
Naoya Fujikawa ${ }^{1}$ Taku Yamashita ${ }^{1}$ \\ ${ }^{1}$ Department of Otorhinolaryngology-Head and Neck Surgery, \\ Kitasato University School of Medicine, Tokyo, Japan \\ Int J Pract Otolaryngol 2020;3:e1-e5.
}

\begin{abstract}
Address for correspondence Naoya Fujikawa, Department of Otorhinolaryngology-Head and Neck Surgery, Kitasato University School of Medicine, 1-15-1 Kitasato, Minami-ku, Sagamihara-shi, Kanagawa-ken, 252-0374, Japan (e-mail: oaksfootball.51@gmail.com).
\end{abstract}

\begin{abstract}
Keywords

- peritonsillar abscess

- blood tests

- deep neck abscess

Background Based on the background factors and results of blood tests in patients with peritonsillar abscess, we investigated the factors involved in the prolongation of hospitalization and progression to deep neck abscess of these patients.

Objective and Methods We studied the data of 113 patients with peritonsillar abscesses (including those in whom the condition progressed to deep neck abscesses) who were hospitalized at our department during the 3-year period from August 2014 to August 2017. Data of patients who needed hospitalized treatment for 7 days or more, including the age, body mass index (BMI), sickness period, white blood cell count, serum C-reactive protein (CRP), serum total protein, serum albumin, blood glucose, blood $\mathrm{HbA1c}$, and estimated glomerular filtration rate (eGFR) at the first examination, and the neck factors in the cases that progressed to deep cervical abscess were examined using $t$-tests.

Results The blood test items and background factors at the first visit were compared according to the length of hospitalization. The results revealed that prolonged hospitalization was associated with higher values of age, peripheral blood white blood cell count, serum CRP value and blood glucose, and lower values of serum total protein, serum albumin, and eGFR.

Conclusions Factors that were associated with a longer hospital stay in this study were relatively high values of age, peripheral blood white blood cell count, blood glucose and serum CRP, and relatively low values of the serum total protein, serum albumin, and eGFR. The disease duration, BMI, and HbA1c were not identified as significant factors. Stepwise multiple regression analysis to identify factors associated with prolonged hospitalization identified the blood glucose and serum albumin levels measured at the first visit as significant predictors of a prolonged hospital stay and higher severity of the illness. Our findings suggested the importance of measuring these factors for predicting the progression to deep cervical abscess.
\end{abstract}

\section{Introduction}

Peritonsillar abscess is a common condition in the field of otorhinolaryngology; however, due care should be taken because patient background and delayed treatment can cause severe progression, resulting in deep neck abscess with descending mediastinitis.

We examined the background factors of patients with peritonsillar abscess along with factors that contribute to received

August 26, 2019

accepted

November 25, 2019
DOI https://doi.org/

10.1055/s-0040-1702999. ISSN 2569-1783.
Copyright $\odot 2020$ Georg Thieme Verlag License terms

KG Stuttgart · New York
(1) (1) $\odot \circledast$ 
long-term hospitalization and progression to deep neck abscess based on blood test results.

\section{Patients and Methods}

This study was conducted in accordance with the Declaration of Helsinki. Approval for this study was obtained from Kitasato University hospital Institutional Review Board. We analyzed the data of 113 patients with peritonsillar abscesses, including those in whom the condition progressed to deep neck abscesses, who were hospitalized at our department during the 3-year period from August 2014 to August 2017. Treatments included the intravenous administration of antimicrobials following abscess needle aspiration or drainage by external skin incision in 107 patients, and intravenous administration of antimicrobials without surgical treatment in 6 patients. In the present study, flomoxef was used to treat peritonsillar abscess during this period in 99 patients. In the other eight patients, meropenem single-agent, ampicillin/sulbactam, or ceftriaxone/ clindamycin was administered. The length of hospital stay was a mean of 10 days and a median of 5 days (2-200 days). A ttest was used to examine factors involved in patients who required hospitalization for $\geq 7$ days based on age, body mass index (BMI), disease duration until examination, white cell count, C-reactive protein (CRP), total protein, albumin (Alb) level, blood glucose, HbA1c, and estimated glomerular filtration rate (eGFR) levels on blood testing at the time of the initial examination as well as in those who developed neck abscess.

\section{Results}

The patients (79 males and 34 females) had a median age of 36 (7-86) years. The age distribution of the patients is shown in - Fig. 1. The most common patients were those in their 20s through 40 s, and in all age groups, male patients tended to be more common.

Furthermore, the disease duration was a mean of 4.5 days and a median of 4 days (1-14 days). Most patients were examined 3 to 4 days after the appearance of symptoms (-Fig. 2).

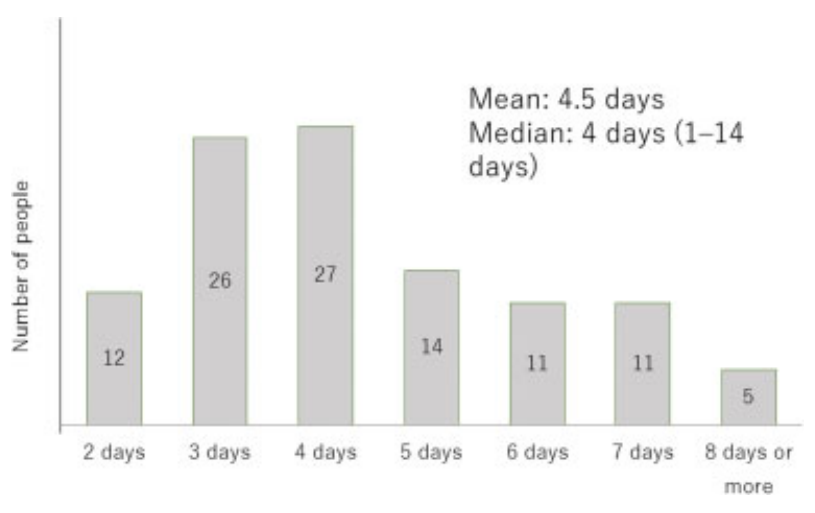

Fig. 2 Disease duration and number of patients. The results show that the disease duration was mostly 3-4 days.

Blood test results at the initial examination revealed that the most common white cell count was 10,000 to $15,000 / \mu \mathrm{L}$ in $52 \%$ patients followed by 15,000 to $20,000 / \mu \mathrm{L}$ in $31 \%$

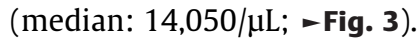

CRP levels were slightly elevated at 0 to $10 \mathrm{mg} / \mathrm{dL}$ in $47 \%$ patients followed by 10 to $15 \mathrm{mg} / \mathrm{dL}$ in $28 \%$ (median: $10.7 \mathrm{mg} /$ dL; - Fig. 4).

For bacterial culture tests, pus was sampled by needle aspiration or incision and drainage of the abscess, and submitted for a culture test using an anaerobic specimen container. Bacteria culture test was performed in 105 patients (92\%), of these, 99 and 6 patients showed positive and negative results, respectively. The culture results were most common in the descending order for Prevotella spp., Micromonas micros, and Fusobacterium spp., with anaerobic bacteria in $49 \%$ phlogogenic bacteria (-Table 1 ).

Furthermore, blood test components at the initial examination, such as white cell count, CRP, total protein, Alb, blood glucose, HbA1c, and eGFR levels, and background factors, such as age, BMI, and disease duration, were compared according to the length of hospital stay (comparison between the $<7$ day hospital stay group $[n=92]$ and $\geq 7$ day hospital stay group $[n=21])$. The results revealed that the higher the age, white cell count, serum CRP level, and blood glucose level, the longer the hospital stay, whereas the lower the total serum protein

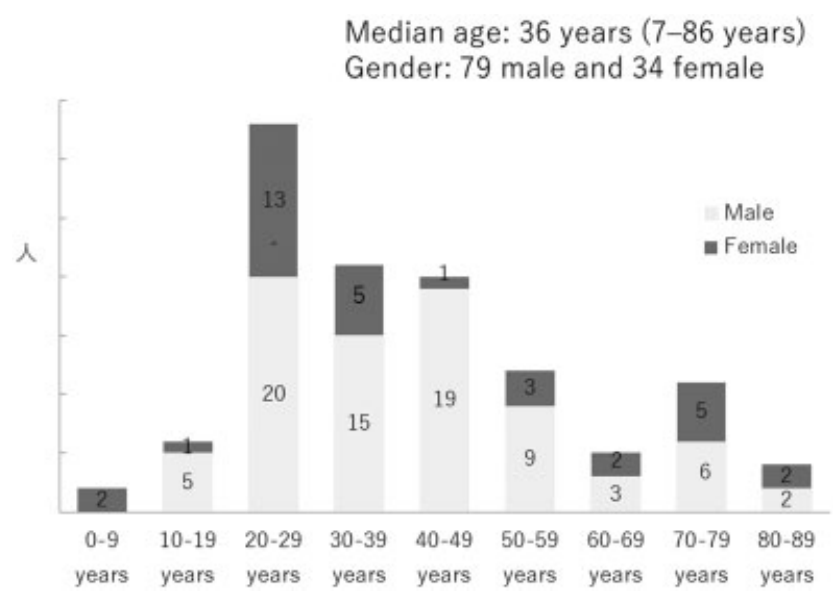

Fig. 1 Number of patients according to age and gender. The results show that most patients were in their 20 s and 40 s, and most patients were male. 


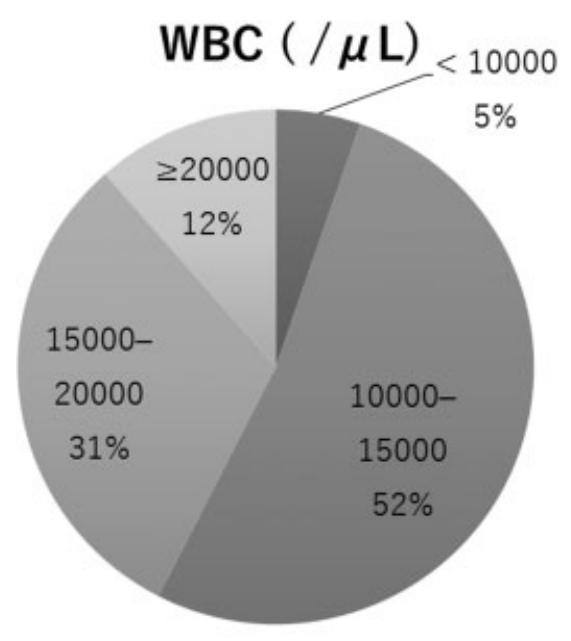

Median: $14050 / \mu \mathrm{L}$

Fig. 3 Distribution of white cell count at the initial examination. The white cell counts were mostly $10,000-15,000 / \mu \mathrm{L}$.

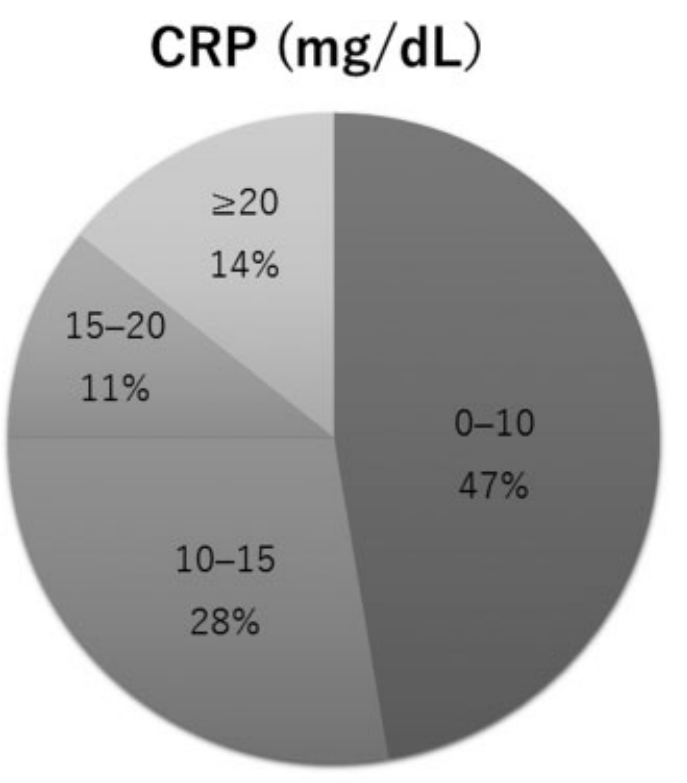

Median: $10.7 \mathrm{mg} / \mathrm{dL}$

Fig. 4 Distribution of CRP levels at the initial examination. The CRP levels were mostly $0-10 \mathrm{mg} / \mathrm{dL}$.

level, Alb level, and eGFR, the longer the hospital stay (-Table 2). Furthermore, when the length of hospital stay is expressed using a mathematical formula according to stepwise multiple regression analysis, then the length of hospital stay $($ number of days $)=88.482+0.135 \times($ blood glucose level $)-$ $24.097 \times$ (Alb level) (adjusted for the degrees of freedom $R^{2}=0.376, p<0.001$ ), where the higher the blood glucose level and the lower the serum Alb level at the initial examination, the longer the hospital stay tends to be. Moreover, the condition progressed to deep neck abscess in 9 of 113 patients who were all treated by lateral neck incision. The length of hospital stay in patients with deep neck abscess was a mean of 45.8 days and a median of 28 days (12-200 days).
Table 1 The culture of peritonsillar abscess at our department

\begin{tabular}{|l|l|}
\hline Cultured bacteria & \\
\hline Prevotella spp. & $13 \%$ \\
\hline Micromonas micros & $13 \%$ \\
\hline Fusobacterium spp. & $12 \%$ \\
\hline Group A Streptococcus pyogenes & $12 \%$ \\
\hline Normal bacterial flora & $10 \%$ \\
\hline Gram-negative anaerobic bacillus & $7 \%$ \\
\hline Group F Streptococcus & $5 \%$ \\
\hline MSSA & $4 \%$ \\
\hline Veillonella spp. & $4 \%$ \\
\hline Group C Streptococcus & $4 \%$ \\
\hline Others & $16 \%$ \\
\hline
\end{tabular}

Abbreviation: MSSA, methicillin-resistant Staphylococcus aureus.

Table 2 The value of each factor according to the length of hospital stay

\begin{tabular}{|l|l|l|l|}
\hline & $\begin{array}{l}<\mathbf{7} \text { days } \\
(\boldsymbol{n}=\mathbf{9 2})\end{array}$ & $\begin{array}{l}\mathbf{2} \text { days } \\
(\boldsymbol{n}=\mathbf{2 1})\end{array}$ & -Value \\
\hline Age $(\mathrm{y})$ & $37.5 \pm 20.2$ & $55.6 \pm 17.1$ & $<0.005$ \\
\hline BMI $\left(\mathrm{kg} / \mathrm{m}^{2}\right)$ & $23 \pm 4.0$ & $24.6 \pm 4.4$ & 0.239 \\
\hline WBC (/BC) & $14,570 \pm 3,440$ & $15,090 \pm 4,740$ & 0.568 \\
\hline CRP (mg/dL) & $9.8 \pm 6.1$ & $18.8 \pm 8.0$ & $<0.005$ \\
\hline $\begin{array}{l}\text { Disease } \\
\text { duration }(\mathrm{d})\end{array}$ & $4.4 \pm 2.0$ & $5.2 \pm 2.9$ & 0.217 \\
\hline $\begin{array}{l}\text { Total proteins } \\
\text { (mg/dL) }\end{array}$ & $7.5 \pm 0.7$ & $6.9 \pm 0.6$ & $<0.005$ \\
\hline $\begin{array}{l}\text { Albumin } \\
\text { (mg/dL) }\end{array}$ & $4.1 \pm 0.5$ & $3.5 \pm 0.3$ & 0.012 \\
\hline $\begin{array}{l}\text { Glucose } \\
\text { level (mg/dL) }\end{array}$ & $117 \pm 42$ & $151 \pm 52$ & 0.025 \\
\hline HbA1c $(\%)$ & $5.9 \pm 0.2$ & $5.9 \pm 1.0$ & 0.901 \\
\hline $\begin{array}{l}\text { eGFR }(\mathrm{mL} / \mathrm{min} / \\
\left.1.73 \mathrm{~m}{ }^{2}\right)\end{array}$ & $90 \pm 21$ & $68 \pm 29$ & $<0.005$ \\
\hline
\end{tabular}

Abbreviations: BMI, body mass index; CRP, C-reactive protein; eGFR, estimated glomerular filtration rate; WBC, white blood cell.

After examining each blood-test component of the initial examination (white cell count, CRP level, total protein level, Alb level, blood glucose level, HbA1c, and eGFR), and background factors (age, BMI, and disease duration) according to the presence or absence of deep neck abscess, we found that higher serum CRP levels, with lower serum total protein, Alb, and eGFR levels, contributed to the progression to deep neck abscess (- Table 3 ).

\section{Discussion}

Peritonsillar abscess is frequently encountered during routine medical practice as abscesses of the head and neck. It is common among individuals in their 20s through 40s. In infants, the onset of peritonsillar abscess is considered rare because the capsule of palatine tonsil is thick, making it 
Table 3 The value of each factor according to the presence or absence of progression to cervical abscess

\begin{tabular}{|l|l|l|l|}
\hline & $\begin{array}{l}\text { Without } \\
\text { progression } \\
(\boldsymbol{n}=\mathbf{1 0 4})\end{array}$ & $\begin{array}{l}\text { With } \\
\text { progression } \\
(\boldsymbol{n}=\mathbf{9})\end{array}$ & $p$-Value \\
\hline Age (y) & $38 \pm 18$ & $68 \pm 12$ & $<0.005$ \\
\hline BMI (kg/m²) & $23.2 \pm 4.34$ & $24.5 \pm 4.54$ & 0.318 \\
\hline WBC (/BC) & $14,680 \pm 4,550$ & $18,590 \pm 4,100$ & 0.209 \\
\hline CRP (mg/dL) & $10.9 \pm 7.9$ & $26.3 \pm 6.5$ & $<0.005$ \\
\hline $\begin{array}{l}\text { Disease } \\
\text { duration (d) }\end{array}$ & $4.4 \pm 2.0$ & $6.1 \pm 3.0$ & 0.12 \\
\hline $\begin{array}{l}\text { Total protein } \\
(\mathrm{mg} / \mathrm{dL})\end{array}$ & $7.5 \pm 0.66$ & $6.4 \pm 0.56$ & $<0.005$ \\
\hline $\begin{array}{l}\text { Albumin } \\
(\mathrm{mg} / \mathrm{dL})\end{array}$ & $4.0 \pm 0.5$ & $3.0 \pm 0.3$ & 0.009 \\
\hline $\begin{array}{l}\text { Glucose level } \\
(\mathrm{mg} / \mathrm{dL})\end{array}$ & $122 \pm 41$ & $145 \pm 80$ & 0.21 \\
\hline HbA1c (\%) & $5.9 \pm 1.0$ & $5.7 \pm 0.1$ & 0.508 \\
\hline $\begin{array}{l}\text { eGFR } \\
(\mathrm{mL} / \mathrm{min} / \\
\left.1.73 \mathrm{~m}{ }^{2}\right)\end{array}$ & $87 \pm 22$ & $54 \pm 32$ & 0.013 \\
\hline
\end{tabular}

Abbreviations: BMI, body mass index; CRP, C-reactive protein; eGFR, estimated glomerular filtration rate; WBC, white blood cell.

difficult for inflammation to spread to the surrounding tissue. $^{1,2}$ Furthermore, peritonsillar abscess onset is common among young men or those in their prime. ${ }^{3}$ In elderly individuals, peritonsillar abscess is rare because of tonsillar atrophy; however, patients who develop deep neck abscess caused by peritonsillar abscess are older than the age group of those with peritonsillar abscess. ${ }^{4}$ In the present study, we found that individuals with peritonsillar abscess were most commonly men in their 20 s through 40 s.

Generally, the disease duration was approximately 4 days, after which the number of patients successively decreased. We could not find many studies that considered the disease duration. However, findings of the present study show that a long disease duration, i.e., delayed examination by a medical institution, caused abscess formation.

Peritonsillar abscess is often caused by multiple infections, whereby the phlogogenic bacteria include aerobic gram-positive cocci, gram-positive anaerobic cocci, and anaerobic gramnegative bacillus present in the oral cavity and pharynx. ${ }^{5}$ Generally, the pathogenic bacteria include 20 to $40 \%$ anaerobic bacteria, 10 to $40 \%$ aerobic bacteria, and 20 to $40 \%$ multiple infections. The isolation frequency of anaerobic bacteria is high (30-60\%), and $87 \%$ of isolated anaerobic bacteria cause multiple infections. Anaerobic bacteria typically include those from Fusobacterium and Prevotella genera. ${ }^{6}$ Takemoto et $\mathrm{al}^{7}$ reported that in patients with peritonsillar abscess, the longer the disease duration, the higher the $\mathrm{pH}$ level of the abscess; in those who developed neck abscesses including peritonsillar abscess, the higher the $\mathrm{pH}$ level, the higher the detection rate of anaerobic bacteria. Furthermore, they reported that this is because aerobic bacteria cause tissue necrosis during the early stage of illness, and during the late stage of illness, anaerobic bacteria proliferation is established as a result of reduced oxidation-reduction potential. Moreover, at our department, the detection rate of anaerobic bacteria was high $(\sim 50 \%)$ due to prompt submission of the aspirated culture for the anaerobic bacteria culture test. This provided similar results to those previously reported for phlogogenic bacteria. Furthermore, the frequency of resistant bacteria among the bacteria detected in peritonsillar abscesses was not very high, and it cannot be said that severe progression will occur or treatment prolonged only because resistant bacteria were detected from clinical findings. ${ }^{6}$ On the other hand, in Tokyo, Tama city region, $6.4 \%$ bacteria detected in the pus culture of peritonsillar abscesses were resistant to cephalosporin-based antimicrobials, whereas bacteria detected in a high rate of $45 \%$ were resistant to quinolone-based antimicrobials ${ }^{8}$; therefore, quinolone-based antimicrobials should be cautiously used. The most common aerobic bacteria were of the Streptococcus genus, among which, Streptococcus anginosu has drawn attention because it contributes to severe progression in deep neck abscesses. Furthermore, it has been reported that Streptococcus milleri group infections promote anaerobic bacteria proliferation, and multiple infection with anaerobic bacteria exacerbated inflammation in a synergistic manner, which is thought to become refractory. ${ }^{9,10}$ In the present study, anaerobic bacteria accounted for the majority of phlogogenic bacteria; the use of antimicrobials that act on anaerobic bacteria is considered; however, taking into account the possibility of the appearance of resistant bacteria, it is preferable to use broadspectrum antimicrobials for a short period.

Recent reports on the mean hospital stay for peritonsillar abscess mostly indicate a mean hospital stay of approximately 7 days. In the present study, we extracted age, white cell count, serum CRP, serum total protein, serum Alb, blood glucose levels, and renal function value as factors that prolong the hospital stay. On the other hand, disease duration, BMI, and HbA1c were not significant factors. That is, severe progression cannot be predicted according to background factors of patients such as the presence of diabetes, degree of obesity, or delayed treatment, but rather according to the severity of inflammation inferred on the basis of test results at the initial examination, and associated signs of malnutrition and dehydration could serve as factors to predict the prolongation of hospitalization and progression to severe illness. The results were the same for the progression to deep neck abscess.

After examining factors that contribute to the prolongation of hospitalization according to a stepwise multiple regression analysis, blood glucose levels and serum Alb levels in the results of the tests performed at the initial examination were suggested to be important factors in predicting the prolongation of hospitalization, severe progression, and patient progress.

A previous report showed that highly obese patients had longer hospital stays ${ }^{11}$; however, in the present study, BMI was not a factor that prolonged hospitalization. Therefore, further studies are needed with a larger subject sample in the future.

\section{Conclusions}

The severity of inflammation, malnutrition, and dehydration obtained from blood data at the initial examination serve as 
more important factors than the patient background, disease duration for the prediction of hospital stay prolongation, and severe disease progression. Among data obtained at the initial examination, we believe that blood glucose levels and Alb levels are useful in predicting the length of hospital stays.

\section{Conflicts of Interest}

None declared.

\section{References}

1 Watanabe T. Peritonsillar abscess and deep neck abscess from an anatomical perspective.JJpn Soc Stomato-pharyngology 2015;28:243

2 Buckley J, Harris AS, Addams-Williams J. Ten years of deep neck space abscesses. J Laryngol Otol 2019;133(04):324-328

3 Kato H, Wada I, Nakada H, et al. A clinical and statistical study of admitted peritonsillar abscess cases. J Jpn Soc Stomato-pharyngology 2006;18:421-428

4 Amatsu H, Kubo M, Sakashita S, et al. Clinical analyses of 103 patients with peritonsillar abscess. Pract Odontol 2007;100:737-742
5 Takenaka Y, Takeda K, Yoshii T, et al. The management of peritonsillar abscess by needle aspiration. Otorhinolaryngol Head Neck Surg 2011;283:1035-1038

6 Watanabe T, Suzuki M. A bacteriological study of peritonsillar abscesses. J Jpn Soc Stomato-pharyngology 2005;17:345-352

7 Takemoto S, Hashimoto M, Sugahara K, et al. A study of the acidic condition in abscesses of the head and neck-Second report. J Jpn Soc Infect Dis Otolaryngol 2007;25:21-24

8 Takahashi R, Ariizumi Y, Kishine N, et al. A study of cases of peritonsillar abscesses in the Tokyo Nishitama area. J Otorynolaryngol Jpn 2017;120:817-824

9 Toyoda K, Kusano N, Saito A. Pathogenicity of the Streptococcus milleri group in pulmonary infections-effect on phagocytic killing by human polymorphonuclear neutrophils. Kansenshogaku Zasshi 1995;69(03):308-315

10 Shinzato T, Saito A. The Streptococcus milleri group as a cause of pulmonary infections. Clin Infect Dis 1995;21(Suppl 3): S238-S243

11 Umibe A, Anazawa U, Kessoku H, et al. Clinical analyses of 115 patients with peritonsillar abscess [in Japanese]. Nippon Jibiinkoka Gakkai Kaiho 2015;118(10):1220-1225 